\title{
Microbiological safety and toxic element contaminants in bivalve shellfish from intertidal mudflats of IKO estuary, Niger delta, Nigeria
}

\author{
Sunday Peter Ukwo**1, Chidi F. Ezeama ${ }^{2}$ and Ofonmbuk Ime Obot ${ }^{3}$ \\ ${ }^{1}$ Department of Food Science and Technology University of Uyo, Akwa Ibom state, Nigeria \\ ${ }^{2}$ Department of Food Science and Technology Michael Okpara University of Agriculture Umudike, \\ Abia State, Nigeria \\ ${ }^{3}$ Department of Fishery and Aquatic Environmental Management, University of Uyo, Akwa Ibom \\ State, Nigeria \\ *E-mail: sonipeter75@gmail.com
}

\begin{abstract}
Bivalve shellfish is considered as delicious and healthy food items in several dietary regimes in the Niger Delta but the accumulation of hazardous substances tend to undermine the nutritional and health benefits derived from their consumption. Four species of bivalve shellfish: Bloody cockle (Anadara senilis), Donax clam (Donax rugosus), Knife clam (Tagelus adansonaii) and Mangrove oyster (Crassosstra gasar) harvested from the brackish water of Iko estuary were assessed of their safety for human consumption. Standard methods of analysis were employed to assess microbiological hazards and toxic element contaminants. Results of microbiological analysis revealed a total viable counts (TVC) lower than the recommended limit (5.7 $\log \mathrm{cfu} / \mathrm{g}$ ) for fresh bivalve molluscs while Vibrio cholerae, Vibrio parahaemolyticus, Salmonella spp, Shigella spp, Listeria monocytogenes and E-coli were far above the stipulated FDA standard for molluscian shellfish. Analysis for toxic elements clearly showed differential selectivity for the ranged of toxic elements. Lead concentration was within the acceptable limit $(1.5 \mathrm{mg} / \mathrm{kg})$. Cadmium concentration in bloody cockle, knife clam and mangrove oyster was higher than the acceptable standard recommended by regulatory agencies for shellfish. The accumulation pattern and tissue burden of bivalve shellfish samples indicated that microbiological hazards and toxic element contaminants were higher in bloody cockle and knife clam when compared to donax clam and mangrove oyster. Therefore, bivalves shellfish harvested from the study location is not considered safe for human consumption without any further treatment and proper processing to reduce the levels of hazards which may pose health risk to the consumers.
\end{abstract}

Keywords: Bivalve, Hazards, Contaminants, Brackish water, Niger Delta

Paper cited: Ukwo, S. P.; Ezeama C. F. and Obot O. I. (2019). Microbiological safety and toxic element contaminants in bivalve shellfish from intertidal mudflats of IKO estuary, Niger delta, Nigeria. South Asian Journal of Food Technology and Environment, 5(2): 846-854.

\section{Introduction}

There is growing scientific concern on the quality and safety of seafood harvested from the estuaries or brackish water ecosystems of the Niger delta region of Nigeria. The intertidal mudflat of brackish waters of the Niger delta is exceptional breeding ground for a vast variety of fish and shellfish. It provides an excellent habitat for diversity of bivalve molluscs shellfish such as Bloody cockle (Anadara senilis), Mangrove oyster (Crassosstrea gasar), Razor or Knife clam (Tagelus andansonaii), Donax clam (Donax rugosus) among others. But the prevailing pollution occasioned by exploration and production of petroleum have impacted negatively on the quality and safety of shellfish from this area (Yakubu, 2017). Many factors influencing seafood safety and quality include microbiological composition, environmental contaminants, water and product handling. Also many critical and lifelong diseases, from diarrheal disease to various forms of cancer have also been connected to unsafe seafood. Hazards 
associated with bivalve shellfish may arise from raw, fresh, minimally processed, packaged, prepared, and stored items. The clinical symptoms of these hazards are dependent on the dosage and the health status of the consumer, ranging from mild to lifethreatening and chronic adverse reactions (Huss et al., 2003).

Bivalve shellfish-associated hazards can be broadly classified into environmental, intrinsic, and process-related, however the environmental hazards are the major class of hazards of concerned. They are caused by exposure of bivalves to microbial pathogens, parasites, toxic metals, and other chemical pollutants from their habitats (Venugopal and Gopakumar, 2017). The number and type of pathogenic bacteria present in marine or estuarine waters depend on seasonal, climatic and anthropogenic factors (Vernocchi et al., 2007). The bacteria found in bivalves can be indigenous to marine or estuarine environments, non-indigenous/enteric bacteria that occur due to faecal contamination and bacteria from cross-contamination during food preparation and processing (Lee et al., 2008). The retention of bacteria by bivalve depends on several factors, such as its form and dimension that influence bacteria adsorption and capture (Silva and Batista, 2008). The feeding physiology of bivalves also determines the accumulation of pathogenic bacteria filtered from the overlying water (Burkhardt and Calci, 2000). According to Lees (2010), hazards posed by the routes of transmission from the environment to humans include the consumption of raw, uncooked or lightly cooked bivalve shellfish, representing a significant health risk to the consumers. Also the bioaccumulations of harmful micro organisms in shellfish are compounded by the traditional consumption of certain bivalve shellfish in raw or only mildly cooked dishes. The most notable examples include Vibrio species, which account for $20 \%$ of all outbreaks of disease (Potasman et al., 2002). The presence and concentration of toxic elements in the aquatic environment, including biota, specifically in bivalve molluscs shellfish can be attributed to natural and anthropogenic sources. Toxic elements particularly mercury, cadmium, lead and arsenic are cumulative in nature and can be assimilated, stored and concentrated by living organisms through the food chain, causing sometimes serious physiological effects.

In several developing countries in Africa, there is a strong economic incentive derived from a sustained demand for bivalve mollusc shellfish as an animal protein source and this is particularly so in Nigeria, Ghana and Cameroon. They are believed to provide an inexpensive source of protein with high biological value, essential minerals such as selenium, calcium, iron, phosphorus as well as vitamins (Astorga-Espana et al., 2007). In the Niger delta, harvesting of bivalves has little or no regulatory mechanisms in place and this is further exacerbated by high degree of environmental degradation and aquatic perturbation posed by petroleum exploration activities in this region as well as poor sanitary facilities, which require extra attention to curtail the incidence of shellfish-borne diseases (Wala et al., 2016; Zabbey and Babantunde, 2015). Due to the health hazards inherent with consumption of bivalves, many developed countries have enacted regulations based on microbiological analysis of water and/ or bivalve flesh. Most of these regulations use coliform counts as an indication of faecal contamination. The objective of this study is to assess microbiological hazards and toxic element contaminants of fresh bivalve species harvested from the brackish water of the Niger delta. This study will assess their suitability for human consumption and provide baseline information on the quality and safety of fresh bivalve species produced from this area.

\section{Materials and Methods}

Sample Collection: The study area lies along Atlantic Coastline in the Niger Delta region of Nigeria at $\left(4^{\circ} 20-4^{\circ} 35^{\prime}\right.$ and $\left.7^{\circ} 40^{\prime}-7^{\circ} 50^{\prime}\right)$. The Niger Delta sustains Africa's largest, and the world's third mangrove forest, bearing not only Nigeria's most abundant petroleum resources, but also a diversified ecosystem, and numerous aquatic and terrestrial organisms (Okonkwo et al., 2015). The coastal waters of the Niger Delta provide an excellent habitat for diversity of fish, shellfish and other seafood products. The location was chosen because of availability of the four (4) species of bivalve molluscs which served as an important delicacy and food for indigenous people. This location is essentially estuarine in nature with brackish water characterized by 
fine sandy beaches surrounded by mangrove swamp and intertidal mudflat in which Nypa vegetation dominates. The hydrology of this locations presents a cyclic pattern with large amount of precipitation (rainfall) and tidal interplay with annual rainfall level of about $2500 \mathrm{~mm}$, an average humidity level of over $85 \%$ and the temperature range of $18-30^{\circ} \mathrm{C}$. This coastal environment suffers from environmental degradation occasioned by exploration and production of petroleum, liquefied natural gas production and spillage of petroleum products

Sample preparation and Treatments: At the laboratory, the bivalves were promptly cleaned of incrustations, washed in distilled water to remove all dirt. Samples were shucked with sterile scapel to extract the flesh and intravalvular fluid into sterile container. The extracted tissues were homogenized for $60 \mathrm{~s}$ in a stomarcher (Sewad Laboratory Stomacher 400, England) and a portion taken for microbiological analysis while the other portion were stored at $-20^{\circ} \mathrm{C}$ in a scanfrost deep freezer for various toxic element analysis Microbiological Analysis: Microbiological analysis includes enumeration and isolation of pathogenic microorganism in fresh bivalve tissues. For the purpose of this study, microorganisms indigenous to marine or estuarine environment and those from faecal contamination or enteric origin were assessed. The total viable count or aerobic plate count were carried out using the Pour Plate Method as outlined by Hatha et al., (2005). The method of Food and Drug Administration (FDA) as outlined by Feng et al., (2002) was used for enumeration of $E$ coli. The isolation and enumeration of salmonella spp and shigella spp were carried out using a selective and differential medium, salmonella shigella agar. Salmonella do not ferment lactose but produce hydrogen sulphide resulting in colonies appearing colourless but black in centres while shigella spps do not ferment lactose or produce hydrogen sulphide hence the colour appears colourless on the media. Analysis for Vibrio parahaemolyticus and Vibrio cholerae were performed according to the ISO/TS 21872-1 method (ISO, 2007). The green characteristic colonies were presumptively selected as Vibrio parahaemolyticus while yellow characteristics colonies were selected as $V$. cholerae. Enumeration of Listeria monocytogenes was done according to the method of ISO11290-1 (ISO, 2004). Morphological, physiological, biochemical and other confirmatory tests were carried out on the isolates to ascertain the organisms.

Analysis for Toxic element contaminants of bivalve: The levels of toxic element present in the bivalve samples were determined using a perkin - Elmer model 3030 Atomic Absorption spectrophotometer (AAS) at their respective lamp and wavelength. Standard stock solution of the element to be analysed were prepared, diluted to the corresponding working standard solution for recovery experiment according to the methods as outlined by Onwuka (2018). The wet ashing method as outlined by Onwuka (2018) was used to determine the concentration of toxic element in the bivalve samples. The method of preparation and digestion procedure as outlined by AOAC (2010) for biological sample was also employed.

Assessment of bioaccumulation factor: Bioaccumulation factor (BAF) is multipliers used to estimate concentrations of chemicals that can accumulate in tissues through any route of exposure (Benson et al., 2011). It can also be referred to as bio-concentration factor (BCF) for aquatic invertebrates. The BCF of the bivalve samples for specific toxic elements at the study location were determined for different bivalve samples as the ratio of the concentration of heavy metal in animal tissue to that of concentration of heavy metal in water sample.

Data Analysis: All the analyses were carried out in triplicate and the experimental data generated were statistically analyzed using one way analysis of variance (ANOVA) using SPSS version 16.0. Duncan multiple range test was used to separate the means at $\mathrm{p}<0.05$ significant differences.

\section{Results and Discussion}

Microbiological Hazards in bivalve shellfish Microbiological hazards in surface water and bivalve mollusc shellfish from Iko brackish water (Table 1) indicates a total viable counts (TVC) ranging from 3.48-3.85 $\log \mathrm{cfu} / \mathrm{g}$. There was no significant difference (P>0.05) between the TVC for bloody cockle and knife clam as well as between donax clam and mangrove oyster. However, significant difference $(\mathrm{P}<0.05)$ existed between TVC for 
the surface water sample and bivalve mollusc samples. The highest value for Vibrio cholerae (3.30 log cfu/g) was isolated in bloody cockle followed by donax clam (3.10 logcfu/g) while the surface water sample had the least value of $2.10 \log \mathrm{cfu} / \mathrm{L}$. Vibrio cholerae was not detected in knife clam while Vibrio parahaemolyticus was not also isolated in knife clam and mangrove oyster. Salmonella spp. was isolated from the surface water and all the bivalve shellfish samples while Shigella spp was not isolated in mangrove oyster. The highest count for Salmonella spp and Shigella spp were noted in mangrove oyster (3.30 log $\mathrm{cfu} / \mathrm{g}$ ) and bloody cockle (3.11 log cfu/g) respectively. Listeria monocytogenes was not isolated in the brackish water, donax clam and mangrove oyster. E coli were isolated in all the samples analysed. The highest count was observed in brackish water samples. But values indicated no significant difference in the $E$ coli counts between that of brackish water and all the bivalve shellfish samples under investigation. The cumulative microbiological hazards indicated that bloody cockle had the highest hazards loads followed by knife clam while donax clam accumulated the least microbiological hazard load. Bioaccumulation of harmful micro-organisms in bivalve molluscs have been attributed to various outbreaks of bivalve - associated infections globally. The threats posed by microbial hazards are compounded by traditional consumption of certain bivalve species in raw or mildly cooked dishes. The total viable count (TVC) gives a quantitative estimate of both viable and non-viable cells in bivalve tissues. As regard to current legislation, the TVC for bivalve molluscs harvested from the Niger Delta coastal waters were lower than the recommended limit (5.7 $\log \mathrm{cfu} / \mathrm{g}$ ) for a good quality fresh bivalve molluscs as outlined by the centre for food safety and applied nutrition (CFSAN, 2003) of the US Food and Drug Administration. The TVC recorded in his present study was similar to values obtained by Anaclato et al., (2013) in Portugal. Vibrios are primarily associated with estuarine and coastal marine environment. Vibrio cholerae and vibrio parahaemolyticus have been implicated in food poisoning associated with seafood consumption especially from countries with high ambient temperature and where shellfish are consumed raw (Lee et al., 2008). The Vibrios are involved in the transmission and epidemiology of disease leading to outbreaks at endemic epidemic and pandemic levels (Goel et al., 2010). Microbiological standard for shellfish as outlined by FDA (2009), indicated that Vibrio choleae should be absent in seafood for human consumption while the count of Vibrio parahaemolyticus should not exceed 1000 $\mathrm{cfu} / \mathrm{g}$. Salmonella and Shigella are nonindigenous/enteric bacteria that occur due to faecal contamination of the estuarine waters. These enteric pathogens from the polluted environment can enter the bivalve during feeding where sea water is being filtered into their gut. Consumption of bivalve with these bacteria usually results in infectious diseases such as typhoid fever and other serious salmonellosis in case of Salmonella Spp and bacillary dysentery or shigellosis in the case of Shigella Spp (Potasman et al., 2002). From the public health point of view, the current legislation (FDA 2009) requires total absence of Salmonella and Shigella spps in 25g of bivalves so as to ensure safe product. Listeria monocytogenes is indigenous to marine environment and can be present in bivalve eaten raw or fermented. L monocytogenes have been implicated as a causative agent in invasive listeriosis, meningitis and febrile gastroenteritis (Lee et al., 2008). E. coli is an enteric bacterium which is usually used as an indicator of food safety and sanitary conditions. The presence of this bacterium in food therefore serves as indicator of the present pathogenic micro organisms. E. coli was detected in all bivalve samples analysed indicating that contamination is associated with human activities as the major source of pollutants in this area. The result from this study was similar to the findings observed by Udoh et al., (2017) on fresh water clam from Cross River, in Nigeria. E. coli have been implicated in acute diarrheas and gastroenteritis particularly serotypes such 0148, 0157 and 0124. According to FDA (2009), E-coli in bivalve should equal or less than $230 \mathrm{MPN} / 100 \mathrm{~g}$ and it was observed that the result from this study exceeded the standard. Therefore, in this study, bivalve molluscs harvested from the coastal waters of the Niger Delta are not considered to be safe for human consumption without any treatment or proper coking time. This is due to high accumulation of pathogenic bacteria which posed serious health risk to the consumers. 
Microbiological safety and toxic element contaminants in bivalve shellfish from intertidal mudflats of IKO estuary, Niger delta, Nigeria.

Table 1: Microbiological hazards (Log $\mathrm{cfu} / \mathrm{g})$ isolated from the surface water and bivalve species.

\begin{tabular}{|c|c|c|c|c|c|c|c|}
\hline \multirow{2}{*}{$\begin{array}{l}\text { Microbiological } \\
\text { isolates }\end{array}$} & \multirow{2}{*}{ SW } & \multicolumn{4}{|c|}{ Bivalve species } & \multirow{2}{*}{$\begin{array}{c}\text { Pr>sam } \\
\text {-ples }\end{array}$} & \multirow{2}{*}{$\begin{array}{l}\text { Signif } \\
\text {-icant }\end{array}$} \\
\hline & & BC & DC & $\mathrm{KC}$ & MO & & \\
\hline $\begin{array}{l}\text { Total Viable } \\
\text { count(TVC) }\end{array}$ & $3.48 \pm 0.16^{\mathrm{c}}$ & $3.85 \pm 0.12^{\mathrm{a}}$ & $3.70 \pm 0.05^{\mathrm{b}}$ & $3.80 \pm 0.01^{\mathrm{a}}$ & $3.64 \pm 0.04^{\mathrm{a}}$ & $<0.0001$ & Yes \\
\hline Vibrio cholerae & $1.10 \pm 0.02^{\mathrm{d}}$ & $3.30 \pm 0.04^{\mathrm{a}}$ & $1.26 \pm 0.17^{\mathrm{c}}$ & ND & $2.64 \pm 0.04^{b}$ & 0.003 & Yes \\
\hline $\begin{array}{l}\text { Vibrio } \\
\text { parahaemolyticus }\end{array}$ & $2.23 \pm 0.02^{b}$ & $3.02 \pm 0.18^{\mathrm{a}}$ & $3.01 \pm 0.35^{\mathrm{a}}$ & ND & ND & $<0.001$ & Yes \\
\hline Salmonella spp & $2.43 \pm 0.02^{b}$ & $2.10 \pm 0.02^{\mathrm{c}}$ & $2.10 \pm 1.83^{\mathrm{c}}$ & $3.23 \pm 0.15^{\mathrm{a}}$ & $3.30 \pm 0.09^{\mathrm{a}}$ & $<0.001$ & Yes \\
\hline Shigella spp & $1.15 \pm 0.01^{\mathrm{d}}$ & $3.11 \pm 1.01^{\mathrm{a}}$ & $1.80 \pm 0.05^{\mathrm{c}}$ & $2.83 \pm 0.16^{\mathrm{b}}$ & ND & $<0.001$ & Yes \\
\hline $\begin{array}{l}\text { Listeria } \\
\text { monocytogenes }\end{array}$ & ND & $1.02 \pm 0.02^{\mathrm{b}}$ & ND & $3.02 \pm 0.01^{\mathrm{a}}$ & ND & $<0.001$ & Yes \\
\hline Echerichia coli & $3.14 \pm 0.05^{\mathrm{a}}$ & $3.13 \pm 0.16^{\mathrm{a}}$ & $3.04 \pm 0.13^{\mathrm{a}}$ & $2.97 \pm 0.13^{\mathrm{a}}$ & $2.86 \pm 0.13^{\mathrm{ab}}$ & 0.2321 & No \\
\hline
\end{tabular}

$*$ Values are Means \pm SD of triplicate determination Means in the same row with different superscript are significantly different at $(\mathrm{P}<0.05) . \quad \mathrm{SW}=$ Surface water; $\mathrm{BC}=\mathrm{Bloody}$ cockle; $\mathrm{DC}=$ Donax clam; $\mathrm{KC}=\mathrm{Knife}$ clam; MO=Mangrove oyster, ND= Not Detected

\section{Toxic Element contaminants in bivalve shellfish}

The results obtained from instrumental analyses of surface water and bivalve shellfish samples for toxic elements indicated significant differences $(p<0.05)$ in the concentrations of lead, cadmium, arsenic and mercury (table 2). Lead concentration was highest in donax clam $(0.94 \mathrm{mg} / \mathrm{kg})$ followed by knife clam. The concentration of lead was within the acceptable limits as outlined by EC, (2006) and FDA, (2009). The highest concentration of cadmium $(9.80 \mathrm{mg} / \mathrm{kg})$ was noted in bloody cockle followed by knife clam with $5.53 \mathrm{mg} / \mathrm{kg}$. The concentration of cadmium in bloody cockle, knife clam and mangrove oyster were higher than the safety limits as shown in table 2. Arsenic and mercury were present in the bivalve and surface water samples but that of mercury was within the acceptable limit for molluscian shellfish. The accumulation pattern of toxic elements indicated that bloody cockle had the highest cumulative toxic element concentration of $10.18 \mathrm{mg} / \mathrm{kg}$ followed by knife clam $6.24 \mathrm{mg} / \mathrm{kg}$ while donax clam (2.71) $\mathrm{mg} / \mathrm{kg}$ had the least concentrations of toxic element contaminants. The concentrations and levels of accumulation of toxic elements by bivalve samples in the study area clearly revealed that bivalve shellfish are differentially selective for a range of toxic element and these variations might be influenced by a number of intrinsic (e.g size, age, and sex) and extrinsic factors (e.g metal speciation, Temperature and salinity). Also, the concentration of toxic elements in the tissue of marine invertebrates depends on the accumulation strategy adopted by each species for each element (Sarkar et al., 2008). This strategy results from net differences between rate of absorption and excretion of elements, the permeability of the body surface, and the nature of the food and the efficiency of the osmo regulatory system present (Benson et al., 2017). Bivalve molluscs have been extensively used as a model organisms in environmental studies of water quality and biomonitoring agent hence the results from this study reflects the level of contamination of the Niger Delta environment as well as the safety of bivalve molluscs consumed in this area. According to FAO (2003), lead concentration above acceptable limits $1.5 \mathrm{mg} / \mathrm{kg}$ in bivalve tissue is unacceptable and can pose health risk to the consumers. Cadmium concentration above legal limit as well as the present of arsenic in the tissue of bivalve mollusc is dangerous to the health of the consumers. The concentration of toxic elements in the tissue of bivalve molluscs from this study were higher when compared to values reported by Edoghotu et al., (2015) at B/Dere in Ogoni land. The values are also lower when compared with the values reported by Sarkar et al., (2008), in bivalve molluscs at Sunderban mangrove Wetland at Bay of Bengal in India. Toxic elements are assimilated, stored and concentrated by living organisms through food chain causing serious toxic effect to humans. The toxicity of those elements are due to their ability to replace other metals in the active 
sites of enzymes, form complexes and precipitates with enzyme metals or other groups involve in metabolism, catalyzes the breakdown of essential metabolites as well as combined with membranes, thereby altering their permeability and hindering other elements in their electrochemical functions in human system (Burger and Gochfield, 2005;
FAO, 2003). The discharged effluents alongside the activities such as artisanal refining of petroleum product and pipeline vandalization has negatively affected the environment resulting in elevated toxic element concentrations in seafood from these locations which raised serious concern about their safety for human consumption.

Table 2; Toxic Element concentrations in the surface water $(\mathrm{mg} / \mathrm{L})$ and bivalve species $(\mathrm{mg} / \mathrm{kg})$.

\begin{tabular}{|l|c|l|l|l|l|l|l|}
\hline \multirow{2}{*}{$\begin{array}{c}\text { Toxic } \\
\text { elements }\end{array}$} & \multirow{2}{*}{$\mathrm{SW}$} & \multicolumn{5}{c|}{ Bivalve species } & \multirow{2}{*}{$\begin{array}{c}\text { EC, } \\
\text { FDA, }\end{array}$} \\
\cline { 3 - 7 } & & $\mathrm{BC}$ & $\mathrm{DC}$ & $\mathrm{KC}$ & $\mathrm{MO}$ & 2006 & 2009 \\
\hline Lead $(\mathrm{Pb})$ & $0.005 \pm 0.02^{\mathrm{e}}$ & $0.18 \pm 0.02^{\mathrm{d}}$ & $0.94 \pm 0.03^{\mathrm{a}}$ & $0.51 \pm 0.08^{\mathrm{b}}$ & $0.25 \pm 0.04^{\mathrm{c}}$ & 1.5 & 1.7 \\
\hline Cadmium $(\mathrm{Cd})$ & $0.026 \pm 0.03^{\mathrm{e}}$ & $9.80 \pm 0.05^{\mathrm{a}}$ & $1.75 \pm 0.01^{\mathrm{d}}$ & $5.53 \pm 0.15^{\mathrm{b}}$ & $4.25 \pm 0.04^{\mathrm{c}}$ & 1.0 & $3-4$ \\
\hline Arsenic $(\mathrm{As})$ & $0.003 \pm 0.02^{\mathrm{e}}$ & $0.05 \pm 0.01^{\mathrm{a}}$ & $0.01 \pm 0.01^{\mathrm{b}}$ & $0.07 \pm 0.01^{\mathrm{a}}$ & $0.01 \pm 0.01^{\mathrm{b}}$ & - & - \\
\hline Mercury $(\mathrm{Hg})$ & $0.001 \pm 0.01^{\mathrm{c}}$ & $0.15 \pm 0.01^{\mathrm{a}}$ & $0.01 \pm 0.01^{\mathrm{d}}$ & $0.13 \pm 0.10^{\mathrm{b}}$ & $0.07 \pm 0.01^{\mathrm{c}}$ & 0.5 & 1.0 \\
\hline
\end{tabular}

$*$ Values are Means \pm SD of triplicate determination Means in the same row with different superscript are significantly different at $(\mathrm{P}<0.05) . \quad \mathrm{SW}=$ Surface water; $\mathrm{BC}=\mathrm{Bloody}$ cockle; $\mathrm{DC}=$ Donax clam; $\mathrm{KC}=\mathrm{Knife}$ clam; MO=Mangrove oyster

Trace metal accumulation based on bioconcentration factor

The bioconcentration factor (BCF), computed for bivalve shellfish is presented in Table 3. The results show a more significant increase in trace metal levels in bivalve shellfish samples than in the surface or brackish water samples. BCF values for trace metals in bivalve shellfish increases as the concentration of the toxic elements increased in the bivalve samples. Relatively high concentration factors were observed for $\mathrm{Cd}$; bloody cockle (376.9), Knife clam (212.7), mangrove oyster (163.5) Enhanced bioconcentration factors for these toxic elements in tissues of bivalve shellfish show that the organisms may serve as good bioindicators for monitoring metals in polluted aquatic ecosystems. However, BCF values found for $\mathrm{Pb}$ and $\mathrm{Cd}$ were comparatively higher than those of As and $\mathrm{Hg}$. This may suggest that bivalve shellfish retains more $\mathrm{Pb}$ and $\mathrm{Cd}$ than other toxic elements in the aquatic ecosystem. According to Benson et al., (2017), Oysters and mussels, which have been reported to accumulate $\mathrm{Cd}$ in their tissues at upto 100,000 times levels observed in water environments where they live. Such toxic element accumulation levels in bivalve shellfish found in the present study complement the reports that the concentration of toxic elements in the tissue of marine invertebrates depends on the accumulation strategy adopted by each species for each element (Sarkar et al., 2008). Therefore, our results indicate that bivalve shellfish serves as a sentinel organism for the biomonitoring of toxic elements in fresh water ecosystems.

Table 3: Toxic Element accumulation levels in bivalve tissue based on bioconcentration factor

\begin{tabular}{|l|l|l|l|l|}
\hline \multirow{2}{*}{ Toxic elements } & \multicolumn{3}{c|}{ Bivalve species } \\
\cline { 2 - 5 } & \multicolumn{1}{|c|}{$\mathrm{BC}$} & \multicolumn{1}{c|}{ KC } & \multicolumn{1}{c|}{ KC } \\
\hline Lead $(\mathrm{Pb})$ & 36.0 & 188.0 & 102.0 & 50.0 \\
\hline Cadmium $(\mathrm{Cd})$ & 376.9 & 67.3 & 212.7 & 163.5 \\
\hline Arsenic $(\mathrm{As})$ & 16.7 & 3.3 & 23.3 & 3.3 \\
\hline Mercury $(\mathrm{Hg})$ & 150.0 & 10.0 & 130.0 & 70.0 \\
\hline
\end{tabular}

$\mathrm{BC}=$ Bloody cockle; $\mathrm{DC}=$ Donax clam; $\mathrm{KC}=$ Knife clam; $\mathrm{MO}=$ Mangrove oyster

\section{Conclusion}

The consumption of bivalve molluscs from the Niger Delta coastal waters posit or exemplify the conflict between food benefits and risks. This is because of the accumulated hazardous substances due to anthropogenic activities which tend to undermine the nutritional and health benefits derived from bivalve consumption. Bivalve shellfish 
samples harvested from the brackish water if Iko Town were loaded with both indigenous marine bacteria vibrios (Vibrio cholera and Vibrio parahaemolyticus) Listeria monocytogenes and enteric bacteria Salmonella spps, Shigella spp and E-coli. The bacteria count of each bivalve samples were higher than the limit stipulated by FDA for shellfish quality. Therefore, the bivalves samples harvested from the locations are not considered safe for human consumption without any further treatment or proper processing. This will help reduce the levels of pathogenic bacteria which may pose health risk to the consumers. The concentrations and level of accumulation of toxic elements by bivalve samples revealed that bivalve molluscs are differentially selective for a range of toxic element and their concentration depends on the accumulation strategy adopted by each species for a particular element. Lead concentration was within the acceptable FAO limit of $1.5 \mathrm{mg} / \mathrm{kg}$ while cadmium, and the present of arsenic were above their acceptable limit in food which are likely to pose health risk to bivalve consumers. This may be attributed to large effluent discharge from petrochemical companies, artisanal refining of petroleum product as well as vandalization and spillage of petroleum product in the Niger Delta. The accumulation pattern and tissue burden of bivalve shellfish samples indicated that microbiological hazards and toxic element contaminants were higher in bloody cockle and knife clam when compared to donax clam and mangrove oyster. Also, BCF values for trace metals in bivalve shellfish increases as the concentration of the toxic elements increased in the bivalve samples. The bioconcentration factor for cadmium was higher when compare to other elements while bloody cockle and knife clam were better bioindicators for environmental monitoring. From these findings it is unlikely that bivalve related infection in the Niger Delta is lacking but it is rather underreported.

\section{References}

Anacleto, P., Pedro, P. Nunes, M. L., Rosa R, and Marques, A., (2013). Microbiological composition of native and exotic clams from Tagus estuary: Effect of season and environmental parameters. Marine Pollution Bulletin. 74: 116-124.

AOAC (2010). Official methods of analysis of Association of Official Analytical Chemist. Washington DC. USA.

Astorga-Espana, M.S., Rodriguez-Rodriguez, E. M. and Diaz-Romero C. (2007). Comparison of Mineral and Trace element concentration in two Mollusus from the Srait of Magellan (Chile). Journal Food composition and analysis, 20 (3-4): 273-279.

Benson, N.U., Anake, W, U., Essien, J. P., Enyong, P., and Olajire. A. A. (2017). Distribution and Risk Assessment of Trace Metals in Leptodius exarata, Surface water and Sediments from Douglas Creek in the Qua Iboe Estuary. Journal of Taibah University for Science, 11: 434-449.

Burger, J. and Gochfeld, M., (2005). Heavy metals in commercial fish in New Jersey. Environmental Research, 99: 403-412.

Burkhardt, W. I. and Calci, K.R. (2000). Selective accumulation may account for shellfish associated viral illness. Applied and Environmental Microbiology, 66(4): 1375-1378

CFSAN (2003). Centre for Food Safety and Applied Nutrition. National Shellfish Sanitation Program. Guide for the control of molluscan shellfish, 357359.

EC (2006). European Commission Regulation (EC) No 1881/2006. Setting maximum levels for certain contaminants in food stuffs. Official Journal of the European Union, L364: 5-24.

Edoghotu A.J., Onwuteaka J., Friday, U., Wokoma, A.O. F. and Bob-Manuel, F.G. (2015). Heavy metals contamination of the sessile bivalve, Crassostrea gasar (mangrove oyster) in post oil spilled brackish water creek of the Niger Delta, Nigeria. Annals of Biological Research ,6 (11): 72-77.

FAO (2003). Review of the State of World Aquaculture. Inland Water Resources and Aquaculture Services.FAO Fisheries Circular, 886: 1-95.

FDA (2009). Food Drugs Administration National Shellfish Sanitation Program guide for the control of molluscan 
shellfish 2007 revisions. Available at: http:// www.cfsan.fda.gov/;ear/nss4toc.html. Accessed: November, 2018.

Feng, P., Weagant, S.D. and Grant, M.A. (2002). Enumeration of Escherichia coli and the coliform bacteria. In: Bacteriological Analytical Manual. US Food and Drug Administration (FDA). Available at http:// www.fda.gov/ Food/FoodScience Research/ Laboratory Methods/ucm064948. Accessed 08 May 2018.

Goel, A.K., Jain M., Kumar P., and Jiang, S. C.(2010) Molecular characterization of Vibrio cholerae outbreak strains with altered $\mathrm{El}$ Tor biotype from southern India. World Journal of Microbiology and Biotechnology, 26 (2): 281-287.

Hatha, A.A.M., Christi, K.C., Singh, R. and Kumar, S. (2005). Bacteriology of the fresh water bivalve clam Batissaviolacea (Kai) sold in the Suva market. The South pacific Journal of Natural Science, 23: 48-50.

Huss, H.H., Ababouch, L. and Gram, L. (2003). Assessment and management of seafood safety and quality. Fisheries technical paper 444. Food Agriculture Organization of the United Nations (FAO) Rome, Italy.

ISO (2004). Microbiology of food and animal feeding stuffs. Horizontal method for the detection and enumeration of $L$. monocytogenes. Part 1: Detection method.

ISO (2007). Microbiology of food and animal feeding stuffs - horizontal method for detection of potentially entropathogenic Vibrio Spp - Part 1: Detection of Vibrio parahaemolyticus and Vibrio cholerae. P. 26.

Lee, R.J., Rangdale, R.E., Croci, L., Hervio Heath, D., Lozach, S. (2008). Bacterial Pathogens in Seafood. In: Børresen, T. (Ed.), Improving seafood products for the consumer. Woodhead Publishing Series in Food Science, Technology and Nutrition No. 158, pp 70.

Lees (2000).Viruses and bivalve shellfish. International Journal of Food Microbiology, 59 (1-2): 81-116.

Okonkwo, C.N.P., Kumar, L. and Taylor, S. (2015). The Niger Delta Wetland
Ecosystem: What Threatens It and Why Should We Protect It? African Journal of Environmental Science and. Technology, 9: 451-463.

Onwuka G. I. (2018). Food Analysis and Instrumentation- Theory and Practice.2nd Edition. Naphtali Prints, Somolu Lagos, Nigeria.

Orban, E., Di Lena, G., Nevigato, T., Casini, I., Marzetti, A., Caproni, R.( 2002). Seasonal changes in meat content, condition index and chemical composition of mussels (Mytilus galloprovincialis) cultured in two different Italian sites. Food Chemistry, 77(1): 57-65.

Potasman, Paz, A. and Odeh, M. (2002). Infectious Outbreaks Associated with Bivalve Shellfish Consumption: A Worldwide Perspective. Clinical Infectious Diseases, 35: 921-928.

Sarkar, S.K., Cabral, H., Chatterjee, M., Cardoso, I., Bhattacharya, A., Satpathy, K.K., and Alam, M.A. (2008). Biomonitoring of heavy metals using the bivalve mollusks in Sunderban Mangrove Wetland, Northeast Coast of Bay of Bengal. (India): Possible Risks to Human health. Clean, 36 (2): 187-194.

Silva, H., and Batista, I. (2008). Produção, salubridade e comercialização de moluscos bivalves em Portugal. Publicações avulsas do IPIMAR, Lisboa, Portugal, vol. 20, 171 pp.

Udoh, D.I., Udo, I.U. and Udoh, E.I. (2017). Microbiological analysis of the Freshwater Clam (Galatea paradoxa, BORN 1778)) caught from Cross River, Nigeria. Nigerian Journal of Agriculture, Food and Environment. 13(3): 59-64.

Venugopal, V. and Gopakumar, K., (2017). Shellfish: Nutritional Value, Health Benefits and Consumer Safety. Comprehensive Reviews in Food Sc. and Food Safety, 16: 1219-1242

Vernocchi, P., Maffei, M., Lanciotti, R., Suzzi, G., Gardini, F. (2007). Characterization of Mediterranean mussels (Mytilus galloprovincialis) harvested in Adriatic Sea (Italy). Food Control, 18(12): 1575-1583.

Wala, C., Hart, A.I., Babatunde, B.B. and Zabbey, N. (2016). Assessment of 
Microbiological safety and toxic element contaminants in bivalve shellfish from intertidal mudflats of IKO estuary, Niger delta, Nigeria.

Human Health Risk from heavy Metal Loads in fresh water clam, Ergeria radiata, from the Nun River, Nigeria Delta, Nigeria. Journal of Environment and Earth Science, 6 (9): $10-20$.

Yakubu, O.H. (2017). Addressing Environmental Health Problems in Ogoniland through Implementation of United Nations Environment Program
Recommendations: Environmental Management Strategies. Environments, 4(28): 1-19.

Zabbey, N. and Babatunde, B.B. (2015). Trace Metals in Intertidal sediment of mangrove sheltered creeks in Niger Delta. Nigeria. Variability before and after crude oil spillage. African Journal of Environmental Science and Technology, 9 (4): 371-378.

$\begin{array}{ll}\text { Received } & \text { : August, } 2019 \\ \text { Revised } & \text { : October, 2019 } \\ \text { Published } & \text { : December, 2019 }\end{array}$

